\title{
PERFORMANCE AND STABILITY OF AGRONOMIC AND GRAIN QUALITY TRAITS OF LATVIAN SPRING BARLEY VARIETIES
}

\author{
Māra Bleidere ${ }^{1, \#}$, Ilze Grunte ${ }^{1}$, and Linda Legzdina ${ }^{2}$ \\ ${ }^{1}$ Stende Research Centre, Institute of Agricultural Resources and Economics, "Dižzemes", Dižstende, LV-3258, \\ Talsi Municipality, LATVIA \\ 2 Priekuḷi Research Centre, Institute of Agricultural Resources and Economics, 2 Zinātnes Str., Priekuḷi, LV-4126, \\ Priekuḷi Municipality, LATVIA \\ \# Corresponding author, mara.bleidere@arei.Iv
}

Communicated by Zinta Gaile

This study aimed to evaluate the performance and stability of agronomic and grain quality traits of 11 spring barley varieties from the Latvian breeding programme grown in two locations for four years. The study was carried out on 11 Latvian spring barley varieties: nine covered varieties 'Abava', 'Ansis', 'Austris', 'Didzis', 'Gāte', 'Idumeja', 'Jumara', 'Kristaps', and 'Saule PR' and two hull-less varieties 'Irbe' and 'Kornelija'. Plants of the varieties were grown in field trials of the Institute of Agricultural Resources and Economics, at two sites (Priekuli and Stende) during 2014-2017. Varieties 'Didzis', 'Jumara', and 'Ansis' yielded significantly above the grand mean in eight environments (5.70 tha $\left.{ }^{-1} ; L S D=0.476 t \cdot h a^{-1}\right)$. 'Didzis' showed relatively high dynamic yield stability and broad adaptability to all environments $\left(b_{i}=0.90 ; b=1 ; s^{2} d=0.07\right)$. Grain yield for varieties 'Jumara' and 'Ansis' showed specific adaptability to unfavourable environments $\left(b_{i}=\right.$ 0.48 and 0.55 , respectively; $\left.b_{i}<1\right)$. Some covered spring barley varieties were considered to be the best in eight environments with stable and high 1000 grain weight ('Austris', 'Idumeja'), test weight ('Gāte', 'Jumara', 'Austris'), lodging resistance ('Austris', 'Jumara', 'Didzis'), resistance to Pyrenophora teres ('Didzis', 'Saule PR') and Blumeria graminis ('Saule PR', 'Didzis'). Both hull-less barley varieties 'Irbe' and 'Kornelija' were distinguished for high crude protein and B-glucan content.

Key words: Hordeum vulgare, grain yield, Blumeria graminis, B-glucans, $G \times E$ interaction.

\section{INTRODUCTION}

The objective of the Latvian spring barley (Hordeum vulgare L.) breeding programme is to create new varieties suitable for the Latvian agro-climatic conditions and different crop management systems and characterised by high and stable yield, resistance to lodging and diseases, and grain quality appropriate for different directions of end use. The existence of genotype $\times$ environment $(\mathrm{G} \times \mathrm{E})$ interactions entails the evaluation of genotypes in more than one environment. Analysis of genotype interaction with seasons and other agro-ecological conditions can help to obtain information on the adaptability and stability performance of genotypes. The stability of agronomic and grain quality traits of genotypes in different environmental conditions is very important for barley variety recommendation.
Barley grains are used as raw material in feed and malt production, but also in food processing. There is a range of requirements related to the composition of barley grains.

The wide range of geographical locations and climatic conditions in which barley can be cultivated indicates that the genetic background of barley provides wide capabilities for adapting the plant's growth habit to various growing conditions. The growing conditions in the field are a combination of biotic and abiotic environmental variables (Eggert et al., 2010; Kren et al., 2014). The environmental variables and fertiliser can influence the rate and duration of barley grain yield development and composition (Bleidere et al., 2013a; Valkama et al., 2013; Rajala et al., 2017). In the study of Kren et al., (2014) the formation of grain yield was affected 
by individual factors in the following order of importance: year, nitrogen fertiliser and variety.

From a practical point of view, breeders aim to develop cultivars with both a yield stable at a high level and a wide adaptation. Yield stability refers as yield consistency across years, while adaptation has been described as the ability of a genotype to perform well across environments (Lin and Binns, 1988). Selection for yield stability is complicated since the required number of test environments exceeds the common capacity of cereal breeding programmes (Muhleisen et al., 2014; Lui et al., 2017).

Several statistical methods including parametric and nonparametric have been proposed as effective for the analysis of adaptation and yield stability for different crops (Kang and Pham, 1991; Mohammadi and Amir, 2008; Ferreira et al., 2016; Abdipour et al., 2017). Joint regression of the mean performance of a genotype on an environmental index $\left(b_{i}\right)$ (Eberhart and Russell, 1966) is the most popular approach. Regression coefficients provide additional information on genotype responses in conditions that have been favourable for certain traits. The deviation from regression $\left(s^{2}{ }_{d}\right)$ is used as a measure of phenotypic stability of the tested genotypes in this approach (Becker and Leon, 1988).

For end-users, such as maltsters, millers and bakers, consistency in quality characteristics of cultivars is very important, regardless of changing variety ranks. The main compounds of barley grain that determine the quality and also grain yield are starch, protein and B-glucans. A high stability of raw material quality is a desirable and important feature, since it guarantees constant procedures and low product loss during processing (Grausgruber et al., 2000). Also grain physical traits such as 1000 grain weigh and grain test weigh are important production parameters that affect the profitability of cereal cultivation. The concept of optimal genotype stability and response for quality parameters differs somewhat from that conventionally used to describe yield stability (Peterson et al., 1992). Quality parameters follow a static concept of stability, meaning that a stable genotype is defined as one having an unchanged performance regardless of any variation in environmental conditions (Becker and Leon, 1988). With breeding and selection breeders try to create barley varieties of high grain yield, high test grain weight, low (for malting barley) protein or high (for feed barley) protein content and high starch content, which will also be less affected by environment and to variation of these attributes (Bertholdsson, 1999).

Due to global warming, and potential climate abnormalities associated with it, agricultural productivity highly depends on the use of germplasm that has to be continuously improved by plant breeders to become tolerant to various biotic and abiotic stresses that severely affect growth and yield of crops (Pandey et al., 2017). Therefore, the agronomic traits of barley and stability of these traits have great importance for the breeder to match the demand of farmers and producers. Variation of yield and other agronomic traits of spring barley under Baltic conditions over several years and locations have been objectives of several studies (Ingver et al, 2010; Kolodinska-Brantestam et al, 2010; 2014; Tamm et al., 2015). Several studies of genotype by environment interactions and yield stability under Latvian growing conditions have been reported on barley genotypes under conventional (Bleidere and Grunte, 2008; Bleidere et al., 2012; Bleidere and Grunte, 2012) and organic management systems (Locmele et al., 2017; Bleidere et al., 2018). This study aimed to evaluate the performance of agronomic and grain quality traits and their stability of 11 Latvian spring barley varieties grown in two locations during four years.

\section{MATERIALS AND METHODS}

The study was carried out for 11 Latvian spring barley varieties including nine two-row covered varieties and two two-row hull-less varieties (Table 1).

Plants of the varieties were grown in the field trials of Institute of Agricultural Resources and Economics, Priekul,i Research Centre (latitude $57.1412^{\circ} \mathrm{N}$, longitude $22.5367^{\circ} \mathrm{E}$ ) and Stende Research Centre (latitude $57.3148^{\circ} \mathrm{N}$, longitude $25.3388^{\circ} \mathrm{E}$ ), during growing seasons from 2014 to 2017. The field trials at each location were arranged by a randomised complete block design and grown in three replicates in $6.5 \mathrm{~m}^{2}$ plots in Priekuli and $10 \mathrm{~m}^{2}$ field plots in Stende.

Sowing rate was 400 germinable seeds $\mathrm{m}^{-2}$.

All soil management practices were carried out as recommended for barley growing. Pre-crops and soil characteristics in the field trial locations are presented in Table 2. Herbicides and insecticides were used for weed and insect control in both sites. In order to evaluate infection with leaf diseases no fungicides were applied. The yield was harvested by a small plot combine 'Hege 140' and Wintersteger Classic. One representative sample was formed from the three replications for grain quality assessments.

Data were recorded for yield $\left(\mathrm{t} \cdot \mathrm{ha}^{-1}\right)$, resistance to lodging (9 - best; 1 - worst) and leaf diseases net blotch (caused by Pyrenophora teres), and powdery mildew (caused by Blumeria graminis) (0 - no infection, 9 - very high infection; flag leaf is infected more than $80 \%$ ), and 1000 grain weight (ISTA method; Contador Electronic Seed Counter/Pfeuffer Germany was applied). Barley grain test weight, protein, starch and B-glucan content $\left(\mathrm{g} \cdot \mathrm{kg}^{-1}\right)$ were determined with an Infratec 1241 Grain Analyzer (Foss Tecator AB, Sweden).

Yield data was statistically analysed using analysis of variance (ANOVA) in Agrobase Gereration II SQL version 37.2.4 for all varieties and covered varieties separately. The model Genotype $(\mathrm{G})+$ Year $(\mathrm{Y})+$ Location $(\mathrm{L})+\mathrm{G} \times \mathrm{Y}+$ $\mathrm{G} \times \mathrm{L}+\mathrm{Y} \times \mathrm{L}+\mathrm{G} \times \mathrm{Y} \times \mathrm{L}$ was used. The environmental (E) factor in the ANOVA model is defined as the sum of location (L) and year (Y) factors, and genotype $\times$ environment interactions were components such as $\mathrm{G} \times \mathrm{L}, \mathrm{G} \times \mathrm{Y}$ and $\mathrm{G} \times \mathrm{Y} \times \mathrm{L}$. 
Table 1. Latvian spring barley varieties included in the study ${ }^{1}$

\begin{tabular}{|c|c|c|c|c|}
\hline Variety & $\begin{array}{l}\text { Year of } \\
\text { registration }\end{array}$ & Origin & Short description & $\begin{array}{c}\text { End- } \\
\text { use }\end{array}$ \\
\hline Gāte & 1999 & St $6767 / /$ Emir2/Nadja & $\begin{array}{l}\text { two-row, covered, nutans type, middle late, average } \\
\text { height }\end{array}$ & feed, malt \\
\hline Abava & $2001 *$ & $61238 \times$ Domen & $\begin{array}{l}\text { two-row, covered, nutans type, middle late, tall plant } \\
\text { height }\end{array}$ & feed, malt \\
\hline Ansis & 2001 & KM246-3.78/Taifun & $\begin{array}{l}\text { two-row, covered, nutans type, middle late, short plant } \\
\text { height }\end{array}$ & feed, malt \\
\hline Idumeja & 2001 & Imula/Ida & $\begin{array}{l}\text { two-row, covered, erectoid type, early ripening, average } \\
\text { height }\end{array}$ & feed and food \\
\hline Kristaps & 2006 & CF79502/ST 9023 & $\begin{array}{l}\text { two-row, covered, erectoid type, middle late, average } \\
\text { height }\end{array}$ & feed, malt \\
\hline Austris & 2009 & Ansis/WW 8208; by doubled haploid method & $\begin{array}{l}\text { two-row, covered, nutans type, middle early, average } \\
\text { height }\end{array}$ & feed \\
\hline Jumara & 2010 & Baronesse / L-2380 (Ww7291 / Dina) & two-row, covered, average height, middle late & feed \\
\hline Kornelija & 2014 & SCBN852.7/Sauce/3/Mola/Schuri//Arupo*2/Jet & $\begin{array}{l}\text { two-row, hull-less, nutans type, very early ripening, av- } \\
\text { erage height }\end{array}$ & food and feed \\
\hline Saule PR & 2016 & Tunika/L-3118//Otira & $\begin{array}{l}\text { two-row, covered, early, nutans type, short height, early } \\
\text { ripening }\end{array}$ & feed and food \\
\hline Didzis & 2018 & Justina/ M5 (Danuta/Austris) & $\begin{array}{l}\text { two-row, covered, nutans type, average height, middle } \\
\text { early }\end{array}$ & feed and food \\
\hline
\end{tabular}

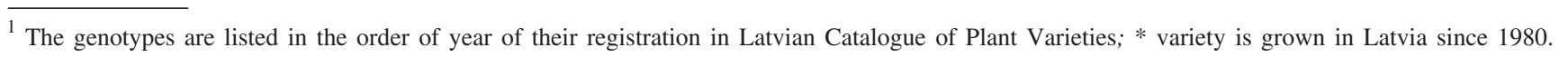

Table 2. Pre-crops, soil characteristics, meteorological parameters and crop management in the field trial locations, 2014-2017

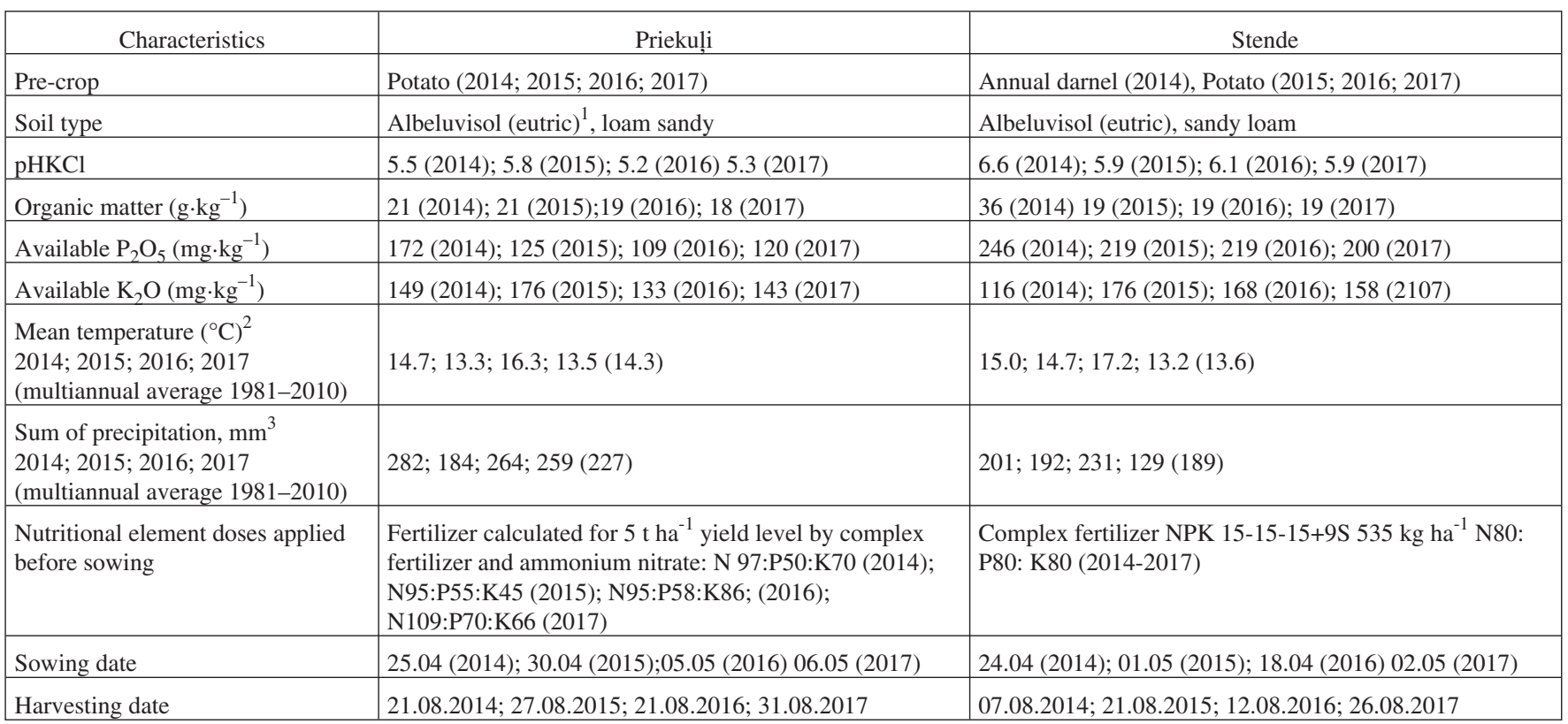

Notes: ${ }^{1}$ World Reference Base, $2014 ;{ }^{2}$ average temperature in May-July; ${ }^{3}$ sum of precipitation in May-July.

ANOVA partitioning of sum of squares were calculated for each factor and their interaction as a percentage from the total. Least significant difference (LSD) values were calculated at the 0.05 probability level for comparisons of genotype performance across all the environments investigated.

The stability of traits was analysed by using some of the most common stability parameters. The mean performance and dynamic concept of stability was evaluated for grain yield where genotype $\times$ environment interaction from two-way analysis of variance was portioned into a heterogeneity of regression coefficient $\left(b_{i}\right)$ (Finlay and Wilkinson, 1963) and sum of squares deviation from regression $\left(\mathrm{s}^{2}{ }_{\mathrm{d}}\right)$ (Eberhart and Russell, 1966). According to the joint regression model, the variety will show broad adaptability with a high yield value, $b_{i}=1$ and $s^{2}{ }_{d}=0$. Slope with $b_{i}<1$ indicates better adaptation to poor environments, while genotypes with $b_{i}>1$ are better adapted to favourable environ- 
ments (Elberhart and Russell, 1966). Phenotypic stability was assessed according to the static concept by using environmental variance $\left(\mathrm{s}_{\mathrm{E}}^{2}\right)$, i.e. the variance of genotype traits recorded across test environments (Nissila, 1992). When the value of the environmental variance $\left(\mathrm{s}^{2} \mathrm{E}\right)$ is small, the stability of a genotype is higher.

In Stende during three vegetation seasons (2014, 2015, 2016) the average monthly temperature was higher than the long-term average, while the amount of precipitation was well above the long-term average. Similar conditions were observed in Priekuli during vegetation seasons of 2014 and 2016. Air temperature and amount of precipitation were lower than the multiannual average values during 2015 in Priekuli. In both locations the vegetation season of 2017 was relatively cool with an above average amount of precipitation in the Priekuli location, and in Stende this vegetation season had low rainfall.

\section{RESULTS}

Grain yield. The results showed that both the genotypes and the environmental conditions significantly $(p<0.01)$ influenced the yield performance of barley varieties (Table $3)$.

According to the analysis of variance, the magnitude of variance due to genotype and year was larger compared to that of location when the data set of all varieties was analysed. Analysing data for covered genotypes only, the magnitude of variance due to genotype was lower, while there was a higher effect of location and interaction effects. Generally, for covered genotypes the magnitude of variances due to genotype, year and location was similar.

Since the genotype $\times$ year and genotype $\times$ location interaction was significant $(p<0.01)$, the phenotypic stability of yield was estimated. Average grain yield in eight environments for Latvian spring barley varieties varied from 3.90 to $6.63 \mathrm{t} \cdot \mathrm{ha}^{-1}$. Varieties 'Didzis', 'Jumara' and 'Ansis' yielded significantly above the grand mean $\left(5.70 \mathrm{t} \cdot \mathrm{ha}^{-1}\right.$; LSD $=0.476 \mathrm{t} \cdot \mathrm{ha}^{-1}$ ) (Table 4$)$.

Among high yielding varieties, 'Didzis' showed relatively high dynamic yield stability and wide adaptability to all environments $\left(b_{i}=0.90 ; b=1 ; s^{2}{ }_{d}=0.07\right)$. Six of eleven varieties tested in the present study could be characterised as suitable to different growing conditions or with wide adaptability to environments since their coefficient of regression did not significantly differ from 1 ; these included varieties 'Austris', 'Kristaps', 'Gāte', and 'Saule PR', which had an average yield over 11 environments that was above the average of all genotypes $\left(5.70 \mathrm{t} \cdot \mathrm{ha}^{-1}\right)$, and 'Abava' had equal yield to the average (Table 4). Grain yield for varieties 'Jumara' and 'Ansis' showed specific adaptability to unfavourable environments $\left(b_{i}=0.48\right.$ and $b_{i}=0.55$, respectively; $\left.b_{i}<1\right)$. Generally, the hull-less barley 'Irbe' and 'Kornelija' showed significantly lower mean yield and lower yield stability compared to other Latvian covered va-
Table 3. Combined analysis of variance of grain yield for nine covered and two hull-less barley genotypes during four years (2014-2017) in two locations (Priekuli, Stende)

\begin{tabular}{|c|c|c|c|c|c|c|}
\hline \multirow[t]{2}{*}{ Source } & \multicolumn{3}{|c|}{$\begin{array}{l}\text { All (covered and hull-less) } \\
\text { genotypes }\end{array}$} & \multicolumn{3}{|c|}{ Covered genotypes } \\
\hline & $\mathrm{df}$ & $\begin{array}{c}\text { Mean } \\
\text { squares }\end{array}$ & $\begin{array}{l}\text { Explained } \\
\text { SS \% }\end{array}$ & df & $\begin{array}{c}\text { Mean } \\
\text { squares }\end{array}$ & $\begin{array}{l}\text { Explained } \\
\text { SS \% }\end{array}$ \\
\hline \multicolumn{7}{|c|}{ Main effects } \\
\hline G & 10 & $14.03 * *$ & 45.1 & 8 & $2.69 * *$ & 18.9 \\
\hline Y & 3 & $4.20 * *$ & 13.5 & 3 & $2.51 * *$ & 16.0 \\
\hline $\mathrm{L}$ & 1 & $2.69 * *$ & 8.7 & 1 & $2.51 * *$ & 19.5 \\
\hline \multicolumn{7}{|c|}{ Interaction effects } \\
\hline $\mathrm{G} \times \mathrm{L}$ & 10 & $0.89 * *$ & 2.9 & 8 & $0.50 * *$ & 3.2 \\
\hline $\mathrm{G} \times \mathrm{Y}$ & 30 & $2.67 * *$ & 8.6 & 24 & $1.55^{* *}$ & 9.9 \\
\hline $\mathrm{G} \times \mathrm{Y} \times \mathrm{L}$ & 30 & $1.21 * *$ & 3.9 & 24 & $0.77 * *$ & 4.9 \\
\hline $\mathrm{Y} \times \mathrm{L}$ & 3 & $1.67 * *$ & 5.4 & 3 & $1.10 * *$ & 7.0 \\
\hline
\end{tabular}

** significant at 0.01 level of probability; df, degrees of freedom; SS, sums of squares; G, genotype; Y, year; L, location.

Table 4. Mean grain yield ( $\mathrm{t} \cdot \mathrm{ha}^{-1}$ ) and stability parameters of barley genotypes over eight environments, 2014-2017

\begin{tabular}{l|ccc|c|c|c}
\hline \multirow{2}{*}{ Variety } & \multicolumn{3}{c|}{ Grain yield } & \multirow{2}{*}{$\mathrm{b}_{1}$} & \multirow{2}{*}{$\mathrm{s}_{\mathrm{d}}{ }^{2}$} & $\mathrm{~s}^{2} \mathrm{E}$ \\
\cline { 2 - 4 } Didzis & $\mathrm{Mean}^{1}$ & $\mathrm{~min}$ & $\mathrm{max}$ & & & \\
\hline Jumara & $6.63 \mathrm{a}^{*}$ & 5.66 & 7.54 & 0.90 & 0.07 & 0.39 \\
Ansis & $6.35 \mathrm{ab}^{*}$ & 4.35 & 8.28 & $0.48^{* *}$ & 0.09 & 1.22 \\
Austris & $6.19 \mathrm{abc}^{*}$ & 5.25 & 8.00 & $0.55^{* *}$ & 0.16 & 0.75 \\
Kristaps & $6.03 \mathrm{bc}$ & 5.62 & 6.57 & 1.27 & 0.16 & 0.14 \\
Gāte & $5.93 \mathrm{bc}$ & 5.26 & 7.36 & 0.70 & 0.11 & 0.56 \\
Saule PR & $5.92 \mathrm{bc}$ & 5.14 & 7.07 & 0.90 & 0.12 & 0.33 \\
Abava & $5.88 \mathrm{bc}$ & 5.01 & 6.51 & 0.80 & 0.18 & 0.33 \\
Idumeja & $5.74 \mathrm{c}$ & 4.97 & 6.41 & 1.17 & 0.08 & 0.22 \\
Irbe & $5.22 \mathrm{~d}^{*}$ & 4.33 & 6.45 & 0.73 & 0.07 & 0.58 \\
Kornelija & $4.91 \mathrm{~d}^{*}$ & 2.90 & 6.27 & $0.48 * *$ & 0.12 & 1.17 \\
Grand mean & $3.90 \mathrm{e}^{*}$ & 2.38 & 4.96 & $0.50 \mathrm{~ns}$ & 0.24 & 0.65 \\
LSD & 5.70 & $\times$ & $\times$ & $\times$ & $\times$ & $\times$ \\
& 0.476 & $\times$ & $\times$ & $\times$ & $\times$ & $\times$
\end{tabular}

${ }^{1}$ values with different letters in a column are significantly different $(p<$ $0.05)$; * significantly different from grand mean yield over 8 environments $(p<0.05)$; ** $\mathrm{b}_{1}$ significantly different from $1(p<0.05)$; ns, not meaningful $(p>0.05)$; $b_{\mathrm{i}}$, regression coefficient; $\mathrm{s}_{\mathrm{d}}^{2}$, deviation from regression; $\mathrm{s}^{2} \mathrm{E}$, environmental variance.

rieties. The results of regression analysis for hull-less variety 'Kornelija' could not be statistically interpreted with confidence as the coefficient of regression $b_{1}$ was not significant $(p=0.07)$. According to the environmental variance $\left(\mathrm{s}_{\mathrm{E}}^{2}\right)$, 'Austris', and 'Abava' followed by 'Gāte' and 'Saule PR' had the lowest variation across environments and 'Irbe' followed by 'Jumara' showed the largest variation (Table 4).

Grain physical traits. Overall the variation of 1000 grain weight $(\mathrm{TGW})$ was significantly $(p<0.01)$ influenced by both main factors $(\mathrm{G}$ and $\mathrm{E})$. The main effect of variation was due to environment (55\%). Mean 1000 grain weight for varieties over eight environments varied to a rather wide ex- 
Table 5. Mean values and environmental stability over eight environments for 1000-kernel weight and test weight of barley genotypes, $2014-2017$

\begin{tabular}{|c|c|c|c|c|c|c|c|c|}
\hline \multirow[t]{2}{*}{ Variety } & \multicolumn{4}{|c|}{ 1000-kernel weight, g } & \multicolumn{4}{|c|}{ Test weight, $\mathrm{g} \cdot \mathrm{l}^{-1}$} \\
\hline & Mean $^{1}$ (rank) & $\min$ & $\max$ & $\mathrm{s}_{\mathrm{E}}^{2}($ rank $)$ & Mean $^{1}$ (rank) & $\min$ & $\max$ & $\mathrm{s}_{\mathrm{E}}^{2}(\mathrm{rank})$ \\
\hline Abava & $49.1 \mathrm{bc}(4)$ & 42.9 & 53.6 & $15.2(7)$ & $713.6 b(4)$ & 667.7 & 751.0 & $673(7)$ \\
\hline Kristaps & $45.3 \mathrm{~d} *(10)$ & 38.5 & 48.2 & $9.2(1)$ & $689.6 d^{*}(10)$ & 633.3 & 735.0 & $969(9)$ \\
\hline Austris & $53.3 \mathrm{a} *(1)$ & 46.6 & 58.8 & $14.3(5)$ & $705.3 \mathrm{c} *(6)$ & 674.7 & 741.0 & $460(3)$ \\
\hline Didzis & $49.8 \mathrm{c} *(3)$ & 43.0 & 53.9 & $11.0(4)$ & $697.0 \mathrm{~cd} *(8)$ & 671.3 & 736.0 & $391(2)$ \\
\hline Idumeja & $51.5 \mathrm{~b} *(2)$ & 43.9 & 59.2 & $19.3(9)$ & $663.0 *(11)$ & 595.3 & 728.0 & $1378(11)$ \\
\hline Gāte & $45.6 \mathrm{~d} *(9)$ & 40.9 & 50.7 & $9.5(2)$ & $717.3 b(3)$ & 676.0 & 758.0 & $541(4)$ \\
\hline Jumara & $47.9 \mathrm{~b}(8)$ & 40.5 & 52.7 & $14.6(6)$ & $708.0 \mathrm{bc} *(5)$ & 657.7 & 740.0 & $552(5)$ \\
\hline Saule PR & $48.4 \mathrm{bc}(6)$ & 39.5 & 54.2 & $20.9(10)$ & $694.0 \mathrm{~cd} *(9)$ & 645.7 & 731.0 & $607(6)$ \\
\hline Irbe & $43.3 \mathrm{e}^{*}(11)$ & 36.8 & 47.2 & $10.2(3)$ & $809.2 \mathrm{a} *(2)$ & 762.0 & 850.0 & $986(10)$ \\
\hline Kornelija & $48.7 \mathrm{bc}(5)$ & 38.7 & 55.1 & $30.7(11)$ & $809.8 a^{*}(1)$ & 782.0 & 832.0 & $341(1)$ \\
\hline $\mathrm{LSD}_{0.05}$ & \multicolumn{4}{|l|}{1.64} & \multicolumn{4}{|l|}{10.90} \\
\hline $\mathrm{SS}_{\mathrm{G}} \%$ & \multicolumn{4}{|l|}{$35 * *$} & \multicolumn{4}{|l|}{$77 * *$} \\
\hline $\mathrm{SS}_{\mathrm{E}} \%$ & \multicolumn{4}{|l|}{$55^{* *}$} & \multicolumn{4}{|l|}{$19 * *$} \\
\hline
\end{tabular}

${ }^{1}$ values with different letters in a column are significantly different $(p<0.05)$; significantly different from grand mean of 1000 -grain weight and test weight over 8 environments $(p<0.05)$; ** significant at $p=0.01$; SS, sums of squares; LSD, Least Significance Difference; G, genotype; E, environment; SS, sums of squares; $\mathrm{s}^{2} \mathrm{E}$, environmental variance.

tent from $43.3 \mathrm{~g}$ for hull-less barley 'Irbe' to $53.3 \mathrm{~g}$ for covered barley variety 'Austris' (Table 5).

Among covered barley varieties, relatively high TGW was also observed for varieties 'Idumeja' and 'Didzis'. Spring barley varieties 'Didzis' and 'Austris' had a TGW significantly above the grand mean and a comparatively low environmental variance, as indicated by the rank of the $\mathrm{s}_{\mathrm{E}}^{2}$ value (Table 5). 'Gāte', 'Kristaps' and 'Irbe', which had the highest TGW static stability over eight environments, had significantly $(p<0.05)$ lower mean values of this trait than the grand mean value $\left(48.3 \mathrm{~g} ; \operatorname{LSD}_{0.05}=1.64 \mathrm{~g}\right)$. The hull-less barley variety 'Kornelija' showed higher TGW (48.7 g) that was similar to that of covered barley and the grand mean value. According to the data analysis of 1000-grain weight, early ripening barley varieties 'Idumeja', 'Saule PR' and 'Kornelija' had higher difference among minimum and maximum values, and the highest values of environmental variance, thus being more sensitive to environmental changes of this trait.

Test weight of hull-less barley variety 'Kornelija' (809.8 $\left.\mathrm{g} \cdot \mathrm{l}^{-1}\right)$ showed also the highest phenotypic stability $\left(\mathrm{s}_{\mathrm{E}}^{2}=\right.$ 341), with the first rank among the varieties (Table 4). 'Abava' and 'Gāte' were the best according to this trait among covered varieties, and variety 'Gāte' had both high and good stability of test weight within eight environments. Comparatively low values of environmental variance of test weight among covered genotypes was shown also by varieties 'Didzis' and 'Austris', ranked the second and third among the varieties.

Grain chemical composition. Mean crude protein for varieties over eight environments also varied in rather wide extent from 106.8 to $149.1 \mathrm{~g} \cdot \mathrm{kg}^{-1}$ and the main effect of variation for this trait was due to genotype (62\%) (Table 6).
Among covered barley varieties, 'Austris' and 'Saule PR' had higher crude protein content (both $121.3 \mathrm{~g} \cdot \mathrm{kg}^{-1}$ ), and 'Austris' together with 'Idumeja' had the highest static stability according to environmental variance $\mathrm{s}_{\mathrm{E}}^{2}$, which could be a good characteristic for both feed and food barley. Three varieties ('Kristaps', 'Didzis' and 'Ansis') were characterised by crude protein significantly $(p<0.05)$ lower than the grand mean value over eight environments, and only 'Ansis' in all environments corresponded to criteria set for protein of malting barley (Table 6). Hull-less barley varieties 'Kornelija' and 'Irbe' had crude protein content significantly $(p<0.05)$ above the grand mean value $(117.7$ $\left.\mathrm{g} \cdot \mathrm{kg}^{-1} ; \mathrm{LSD}=5.80 \mathrm{~g} \cdot \mathrm{kg}^{-1}\right)$. Extremely high average protein content in grains was observed for variety 'Kornelija' (149.1 $\left.\mathrm{g} \cdot \mathrm{kg}^{-1}\right)$. However, according to data analysis the measure of static stability s ${ }^{2}$ for variety 'Kornelija' had the highest value indicating that crude protein of this variety can fluctuate to a rather large extent depending on the environment.

The variation of $ß$-glucan content was significantly $(p<$ $0.01)$ influenced by both main factors. The main effect of variation was due to environment as a factor (52\%). Two covered barley varieties ('Jumara' and 'Saule PR') showed higher B-glucan content in the grain over eight environments. From a nutritional point of view, these varieties could be suitable as grain raw material for food. It was possible to select also varieties accumulating comparatively lower B-glucan content over different environments. The amount of the $\beta$-glucans in the barley grains that is useful for malting cannot exceed $40 \mathrm{~g} \cdot \mathrm{kg}^{-1}$; its stability is also important. Among Latvian varieties, average ß-glucan content that fits malting grain criteria was shown only by variety 'Gāte' (38.4 g. $\left.\mathrm{kg}^{-1}\right)$, although static stability of this trait for this variety was one of the worst. Variety 'Abava' showed 
Table 6. Mean values and environmental stability over eight environments for crude protein and ß-glucan content

\begin{tabular}{|c|c|c|c|c|c|c|c|c|}
\hline \multirow[t]{2}{*}{ Variety } & \multicolumn{4}{|c|}{ Crude protein, $\mathrm{g} \cdot \mathrm{kg}^{-1}$} & \multicolumn{4}{|c|}{ ß-glucans, $\mathrm{g} \cdot \mathrm{kg}^{-1}$} \\
\hline & $\operatorname{Mean}^{1}$ (rank) & $\min$ & $\max$ & $\mathrm{s}_{\mathrm{E}}^{2}($ rank $)$ & $\operatorname{Mean}^{1}$ (rank) & $\min$ & $\max$ & $\mathrm{s}_{\mathrm{E}}^{2}($ rank $)$ \\
\hline Abava & $112.0(8)$ & 9.4 & 12.1 & $8.7(6)$ & $40.0(10)$ & 33.0 & 47.0 & $1.7(2)$ \\
\hline Kristaps & $106.8 *(11)$ & 8.7 & 12.1 & $11.6(8)$ & $42.3(5)$ & 33.0 & 51.0 & $3.8(11)$ \\
\hline Austris & $121.3(3)$ & 11.3 & 13.1 & $2.8(1)$ & $41.7(8)$ & 36.0 & 49.0 & $1.5(1)$ \\
\hline Didzis & $108.5^{*}(10)$ & 9.2 & 12.7 & $10.6(7)$ & $41.8(7)$ & 34.0 & 48.0 & $2.3(4)$ \\
\hline Idumeja & $112.3(7)$ & 10.0 & 12.5 & $5.2(2)$ & $42.3(5)$ & 33.0 & 49.0 & $3(6)$ \\
\hline Gāte & $114.9(6)$ & 10.5 & 12.6 & $5.6(3)$ & $38.4 *(11)$ & 32.0 & 50.0 & $3.6(10)$ \\
\hline Jumara & $115.2(5)$ & 9.8 & 13.2 & $12.9(10)$ & $44.6(3)$ & 36.0 & 50.0 & $2(3)$ \\
\hline Saule PR & $121.3(3)$ & 10.1 & 13.8 & $11.8(9)$ & $43.7(4)$ & 35.0 & 54.0 & $3.4(9)$ \\
\hline Irbe & $123.5^{*}(2)$ & 10.9 & 13.4 & $6.6(5)$ & $46.1 *(2)$ & 37.0 & 53.0 & $3.3(7)$ \\
\hline Kornelija & $149.1 *(1)$ & 14.1 & 16.9 & $15.6(11)$ & $48.1^{*}(1)$ & 39.0 & 58.0 & $3.4(8)$ \\
\hline $\mathrm{LSD}_{0.05}$ & \multicolumn{4}{|l|}{5.80} & \multicolumn{4}{|l|}{3.36} \\
\hline $\mathrm{SS}_{\mathrm{G}}, \%$ & \multicolumn{4}{|l|}{$62 * *$} & \multicolumn{4}{|l|}{$23 * *$} \\
\hline $\mathrm{SS}_{\mathrm{E}}, \%$ & \multicolumn{4}{|l|}{$25 * *$} & \multicolumn{4}{|l|}{$52 * *$} \\
\hline
\end{tabular}

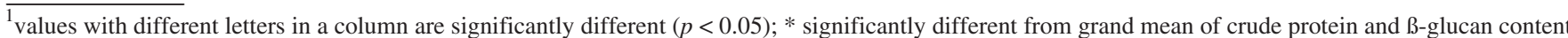
over 8 environments $(p<0.05)$; ** significant at $p=0.01$; SS, sums of squares; LSD, Least Significance Difference; G, genotype; E, environment; SS, sums of squares; $\mathrm{s}^{2}$, environmental variance.

comparatively low ß-glucan content and high phenotypic stability of this quality parameter. Both hull-less barley varieties 'Irbe' and 'Kornelija' were significantly distinguished for comparatively higher higher B-glucan content (46.1 and $48.1 \mathrm{~g} \cdot \mathrm{kg}^{-1}$, respectively), although these varieties occurred mostly in the bottom third of the ranks for the used static stability measures.

Lodging resistance and infection with diseases. Results of average lodging level showed that varieties 'Abava', 'Kristaps', 'Idumeja', and 'Kornelija' under certain environment conditions can be sensitive to lodging (Fig. 1).

Among covered spring barley varieties, 'Austris', 'Jumara', 'Didzis' were considered the best within eight environments according to lodging resistance.

The lowest infection level with net blotch was indicated for varieties 'Didzis', and 'Saule PR' and according to infection with powdery mildew the best results were observed for 'Saule PR' and 'Didzis' (Fig. 1).

\section{DISCUSSION}

Yield stability is central to cope with the expected increased frequency of extreme weather conditions. The interest of breeders is to quantify how the relative performance of genotypes changes between environments. The genetic architecture of phenotypic yield stability was studied for barley by Kraakman et al. (2004) and the findings for this crop indicated low efficiency of indirect selection for yield stability (Muhleisen et al., 2014). In our study the performance of genotypes varied highly significantly from one environment to another as indicated by the significant contribution by environment interaction components such as $\mathrm{G} \times \mathrm{L}, \mathrm{G} \times$

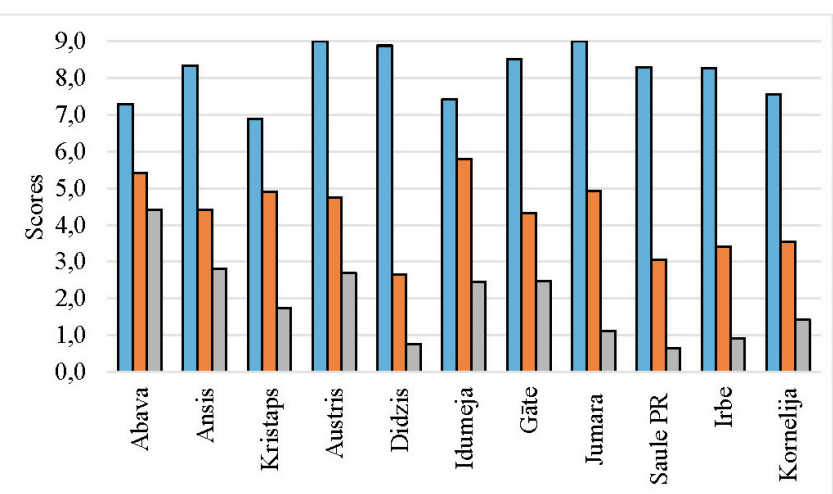

$\square$ Lodging resistance $\square$ Infection with net blotch $\square$ Infection with powdery mildew

Fig. 1. Lodging resistance and infection with leaf diseases of spring barley varieties over eight environments, Priekuli, Stende, 2014-2017 (resistance to lodging: 9-best, 1-worst; net blotch and powdery mildew: 0 , no infection, 9 , very strong infection).

$\mathrm{Y}$ and $\mathrm{G} \times \mathrm{Y} \times \mathrm{L}$ for all genotypes. These sources of genotype $\times$ environment interaction explained $21 \%$ and $25 \%$ of the variance in grain yield of all varieties and covered type varieties, respectively (Table 3). Mean square values showed that $\mathrm{G} \times \mathrm{Y}$ interaction was a more important component of $\mathrm{G} \times \mathrm{E}$ among interaction components determining yield variation. This implies that a single variety could react differently due to specific agro-meteorological conditions of each year of investigation. Sabaghinia et al. (2013) also concluded that the combined analysis of variance showed the significance of the environment, genotype and genotype by environment interaction for barley yield in eleven environments.

According to Lin and Binns (1991), when superiority of genotype in yield performance covers the full range of potential growing conditions, the genotype is generally, widely, 
or broadly adapted. According to the technique described by Eberhart and Russel (1966), an ideal genotype must show high grain yield with wide adaptability $\left(b_{1}=1\right)$ and high stability $\left(\mathrm{s}_{\mathrm{d}}^{2}=0\right)$. Among high yielding varieties in this study, 'Didzis' showed dynamic yield stability and wide adaptability to all environments. Dynamic stability implies a stable yield response across environments, which is always parallel to the mean response of the tested genotypes, i.e. lack of GE interaction. This genotype had a good combination of yield and stability. Genotypes with high yielding genetic potential in specific conditions and poor yield potential in non-target conditions are known as cultivars with specific adaptability. The genotypes adapted to favourable and unfavourable environments have $b_{1}>1$ and $b_{1}<1$, respectively. Regression analysis showed that the varieties 'Jumara' and 'Ansis' showed specific adaptability to unfavourable environments. The measure of dynamic stability depends on the specific set of tested genotypes, unlike the measure of static stability (Becker and Leon, 1988).

Deviation from regression $\mathrm{s}_{\mathrm{d}}^{2}$ was used as a measure of static stability, and additionally environmental variance $\mathrm{s}^{2} \mathrm{E}$ was calculated; a stable genotype tends to maintain constant yield across environments. Evaluating breeding lines for yield stability in eleven environments, Sabaghinia et al., (2013) concluded that the environmental variance measure would be useful for simultaneously selecting for high yield and stability, which is the objective of most breeding programmes. However, Mohammadi and Amir (2008) pointed out that the most stable genotypes would not necessarily give the best yield performance, which was also confirmed by our research results. Overall, neither responsiveness, measured by the regression coefficient $\left(b_{i}\right)$, nor phenotypic yield stability, measured by the deviation from regression $\left(\mathrm{s}_{\mathrm{d}}^{2}\right)$ and environmental variance $\left(\mathrm{s}_{\mathrm{E}}^{2}\right)$, were correlated with grain yield (data not shown), similarly to study of Nurminiemi et al. (1996). Thus, variety 'Abava' with equal yield to the average showed comparatively low values of the deviation from regression $\left(\mathrm{s}_{\mathrm{d}}^{2}=0.08\right)$ and environmental variance $\left(\mathrm{s}_{\mathrm{E}}^{2}=0.22\right)$ (Table 4$)$. This means that the $\mathrm{G} \times$ E interaction effect for this variety was low and that this genotype maintained the same relative effect on the total yield variance in different environments. Yield performance and stability of the old variety 'Abava', which has been grown in Latvia since the 1980 s, is still appreciated by both conventional and organic farmers because of its adaptability to environments with stress factors. According to data from seven environments, including conventional and organic crop management systems (Locmele et al., 2017), variety 'Abava' showed a tendency of wide adaptability with an opposite trend to low yielding environments $\left(b_{i}=0.78\right)$. Overall, the results of the current research confirmed results obtained for 'Abava' under organic growing conditions, where this variety showed comparatively lower average yield and good yield stability according to parameters $b_{1}$ and $s^{2}{ }_{d}$ (Bleidere et al., 2018). Both hull-less barley varieties showed significantly a lower yield level compared to other covered varieties, except 'Idumeja'. This can be explained by the fact that the hull makes up 12 to $15 \%$ of the weight of traditional covered barley. Also, the breeding programme for hull-less barley is relatively new in Latvia.

For evaluation of phenotypic stability for advanced barley lines and selection of superior genotypes across different environments, Abdipour et al. (2017) recommended to use non-parametric stability measures, since calculating procedures are simple and these have a significant and positive correlation with mean yield. Only the variety 'Didzis' showed consistently superior performance across all environments, ranking in the top third of the test entries in all of the test environments (data not shown) and was identified as the most stable genotype according to the non-parametric top ranking test suggested by Fox et al. (1990). In the present study, only parametric measures were used for assessment of both dynamic and static yield stability, because due to the relatively small number of entries these indicators make it possible to identify varieties with high and stable yields sufficiently well. Muhleisen et al. (2014) concluded that precise assessment of yield stability of individual genotypes requires phenotyping in at least 40 test environments for winter barley. However, in practice, selection for yield stability is not practically possible to such an extent, since the required number of test environments exceeds the common capacity of barley breeding programmes.

For barley grain end-users, consistency in quality characteristics of varieties is more important, and therefore for characterisation of stability, for both grain physical and chemical quality parameters the static concept of stability measures will be more informative.

Physical measurements can be advantageous commercially because they are usually more rapid and less expensive than chemical assays. Therefore, the evaluation methods used for grain physical traits could be used as potential early screening tools in barley breeding also for characterisation of grain nutritional quality. 1000-grain weight (TGW) and test weight (TW) are the most important yield components usually used by breeders and also grain processors to indicate grain quality and to predict kernel composition, and therefore stability of these traits is an important feature of a variety. Other studies also concluded that this trait (TGW) for spring barley was influenced by all factors, including genetic, environmental factors and genotype $\times$ environment interaction (Fox et al., 2006; Kolodinska-Brantestam et al., 2014; Tamm et al., 2015). Variety 'Austris' showed the potential to form coarse grains regardless of the differences in growing conditions. Similarly, in another study this variety also showed both the highest 1000 grain weight and its phenotypic stability over ten years under growing conditions of West Latvia (Bleidere and Grunte, 2012). A study conducted by Kolodinska-Brantestam et al. (2014) under Baltic conditions showed that modern spring barley varieties and breeding lines are, in general, characterised with higher TGW than for genotypes from earlier breeding periods, and two-row barley showed significantly higher TGM and TW than six-row barley. There were significant differences in TGW between hull-less barley varieties 'Kornelija' and 'Irbe'. Other studies also confirmed the formation of 
course grains for hull-less variety 'Kornelija', similar to that of covered ones (Bleidere et al., 2013a; Bleidere et al., 2013b; Tamm et al., 2015).

Test weight is a measure of the density of weight per unit of grain volume. Test weight is considered as a more variable indicator of grain quality than 1000-grain weight, because test weight is influenced by the shape and form of grain with dependence on actions like harvesting, awn removal and moisture content. As the hulls of hull-less barley are easily removed during harvesting, both hull-less varieties similarly had significantly higher mean test weight (Table 4) than that of covered barley varieties, resulting in grain physical appearance similar to wheat (Baik and Ullrich, 2008). Similar results were obtained in another study for 'Gāte' and 'Austris', where these barley varieties were the best and the most stable according to test weight over ten years of investigation (Bleidere and Grunte, 2012).

Protein content in barley grain is one of the most important factors on which the quality and value of barley grain raw material for different end-uses such as malting, food and feed is determined. It was confirmed also in other studies that the protein content (Bleidere et al., 2013b) and ß-glucan content (Bleidere, 2006; Sterna et al., 2017) of hull-less barley genotypes is mostly superior compared to that of covered barley varieties grown in Latvia. In several other trials, hull-less variety 'Kornelija' also showed the highest level of protein among the tested barley genotypes (Bleidere et al., 2013; Tamm et al., 2015; Sterna et al., 2017). In a study with wheat, Grausgruber et al. (2000) considered that, although grain chemical parameters have to follow a static concept of stability, nevertheless the quality of a genotype can react to favourable or unfavourable environmental conditions, like other quantitative characters. Differences in both the average crude protein and B-glucan content, and their range values, indicate that in general barley varieties react differently while responding to growth conditions during accumulation of crude protein. In general, evaluation results of basic biochemical parameters showed well that in conditions of Latvia there is a possibility to obtain grains with different biochemical composition, and the results of analysis of variance showed that the choice of the variety is significantly essential.

In the Baltic Sea region, periods of hot weather are expected to become more common, with increase in the summer mean temperature and increase in the frequency and intensity of extreme precipitation events (Raisanen, 2017). This likely would have a negative effect on barley disease spread and plant lodging, and therefore variety resistance to abiotic and biotic stresses is significant for increasing adaptation and stability of agronomic traits (Pandey et al., 2017). Barley variety is an important factor to restrict lodging. In the current study, lodging of plants was observed for barley varieties 'Abava', 'Kristaps, and 'Kornelija', which are characterised with comparatively taller plant height. Plant height is the factor that had the highest positive correlation coefficient with lodging (Matusinsky et al., 2015).
Net blotch (Pyrenophora teres) and powdery mildew (Blumeria graminis) of barley are widespread diseases in Latvia. There was found rather a high variation of infection level within both types of barley grown in Priekuli and Stende locations (Bleidere et al., 2012), and these traits also showed variation among Latvian spring barley varieties (Fig. 1).

This study showed that evaluation of varieties in multiple environments allows better estimation of agronomic values of genotypes, but it must be considered that this requires additional time and expenses. Varieties 'Didzis', 'Jumara' and 'Ansis' yielded significantly above the grand mean in eight environments. Overall, current commercially available Latvian spring barley varieties showed different reaction across changing growing conditions in respect to agronomic and grain quality performance. 'Didzis' showed relatively high dynamic yield stability and broad adaptability to all environments, while, grain yield for varieties 'Jumara' and 'Ansis' showed specific adaptability to unfavourable environments. The covered spring barley varieties 'Austris' and 'Idumeja', were considered the best within eight environments with stable and high 1000 grain weight, and accordingly 'Gāte', 'Jumara', and 'Austris' for test weight. High lodging resistance was shown by 'Austris', 'Jumara', and 'Didzis'; low infection with Pyrenophora teres and Blumeria graminis was shown by barley varieties 'Didzis' and 'Saule PR'. Both hull-less barley varieties 'Irbe' and 'Kornelija' were distinguished for higher crude protein and ß-glucan content. Generally, the presented phenotyping data demonstrated availability of significant genetic variability for covered and hull-less types of barley varieties created in the Latvian spring barley breeding programme. This study focused on and discussed the implications of choosing varieties on yield and agronomic traits performance and showed differences of stability measures among different genotypes. The obtained data set could be useful also for future evaluation of the direction and magnitude of the associations between agronomic and grain quality traits of varieties under Latvian conditions depending on the test location and year of evaluation.

\section{ACKNOWLEDGEMENTS}

Thanks to Dr. Ilmar Tamm from the Estonian Crop Research Institute for assistance with statistical data analysis.

\section{REFERENCES}

Abdipour, M., Vaezi, B., Younessi-Hamzekhanlu, M. Ramazani, S. (2017). Nonparametric phenotypic stability analysis in advanced barley (Hordeum vulgare L.) genotypes. J. Crop Sci. Biotechnol., 20 (4), 305-314.

Baik, B.-K., Ullrich, S. E. (2008). Barley for food: Characteristics, improvement, and renewed interest. J. Cereal Sci., 48, 233-242.

Becker, H. C., Leon, J. (1988). Stability analysis in plant breeding. Plant Breeding, 101 (1), 1-23.

Bertholdsson, N. O. (1999). Characterization of malting barley cultivars with more or less stable grain protein content under varying environmental conditions. Eur. J. Agron., 10 (1), 1-8. 
Bleidere, M., Grunte, I. (2012) Vasaras miežu škirnu 1000 graudu masas un tilpummasas fenotipiskās stabilitātes izvērtējums [Evaluation of 1000grain weight and test weight phenotypic stability for spring barley]. In: Proceedings of the Scientific and Practical Conference "Research for Future of Latvia Agriculture: Food, Feed, Fiber and Energy”, Jelgava, Latvia, 23-24 February 2012. Latvia University of Agriculture, pp. 125-130 (in Latvian). Abstract in English available on

http://agris.fao.org/agris-search/search.do?recordID=LV2012000200 (accessed 27.12.2018)

Bleidere, M., Mežaka, I., Legzdina, L., Grunte, I., Beinarovica, I., Rostoks, N. (2012). Variation of spring barley agronomic traits significant for adaption to climate change in Latvian breeding programmes. Proc. Latvian Acad. Sci., Section B., 66 (1/2), 30-35.

Bleidere, M., Legzdina, L., Tamm, U., Tamm, I., Grunte, I., Locmele, I. (2018). Yield stability, canopy characteristics and seed-borne diseases of spring barley genotypes under organic management. Biol. Agricult. Horticult., 35 (2), 110-122.

Bleidere, M., Zute S., Brunava, L., Bobere, N., Jākobsone, I. (2013a). Yield and grain quality of hull-less spring barley in field trials under different nitrogen management conditions. Proc. Latvian Acad. Sci., Section B., 67 (3), 229-235.

Bleidere, M., Zute, S., Jakobsone, I. (2013b). Characterisation of physical and biochemical traits of hull-less spring barley grain in Latvian breeding program. Proc. Latvian Acad. Sci., Section B., 67 (4-5), 399-404.

Bleidere, M., Grunte, I. (2008). Genetic and environmental effect on grain quality of spring barley. Latvian J. Agron., 11, 33-38.

Bleidere, M. (2006) Variation in endosperm beta-glucan content of different spring barley genotypes. In: Research for Rural Development. International Scientific Conference Proceedings, Vol. 1. Latvia University of Agriculture, pp. 7-11.

Eberhart, S. A., Russell, W. A. (1966). Stability parameters for comparing varieties. Crop Sci., 6, 36-40.

Eggert, K, Wieser, H, Pawelzik, E. (2010). The influence of Fusarium infection and growing location on the quantitative protein composition of (Part II) naked barley (Hordeum vulgare nudum). Eur. Food Res. Technol., 230, 893-902.

Ferreira, D. F., Fernandes, S. B., Bruzi, A. T., Ramalho, M. A. P. (2016). Non-parametric approach to the study of phenotypic stability. Genet. Mol. Res., 15 (1), 1-13.

Finlay, K. W., Wilkinson, G. N. (1963). The Analysis of Adaptation in a Plant Breeding Program. Austral. J. Agricult. Res., 14, 742-754.

Fox, G. P., Kelly, A., Poulsen, D., Inkerman, A., Henry, R. (2006). Selecting for increased barley grain size. J. Cereal Sci., 43,198-208.

Grausgruber, H., Oberforster, M., Werteker, M., Ruckenbauer, P.,Vollmann, J. (2000). Stability of quality traits in Austrian-grown winter wheats. Field Crops Res., 66, 257-267.

Ingver, A., Tamm, I., Tamm, Ü., Kangor, T., Koppel, R. (2010). The characteristics of spring cereals in changing weather in Estonia. Agron. Res., 8, $553-562$.

Kang, M. S., Pham, H. N. (1991). Simultaneous selection for yielding and stable crop genotypes. Agron. J., 83, 161-165.

Kolodinska-Brantestam, A., von Bothmer, R., Rashal, I., Gullord, M., Martynov, S., Weibull, J. (2010). Variation of agronomic traits in Nordic and Baltic spring barley. In: Proceedings of the 10th International Barley Genetics Symposium. Cecarelly, S., Grando, S. (eds.). 5-10 April, 2008, Alexandria, ICARDA, pp. 39-45.
Kolodinska-Brantestam, A., Legzdina, L., Cristensen, T., Weibull, J., von Bothmer, R., Martynov, S., Yndgaard, F., Rashal, I. (2014). Characterisation of agronomic performance of Baltic spring barley material. Proc. Latvian Acad. Sci., Sect. B, 68, (3/4), 119-132.

Kraakman, A. T. W., Niks, R. E., Van den Berg, P., Stam, P, Van Eeuwijk, F. A. (2004). Linkage disequilibrium mapping of yield and yield stability in modern spring barley cultivars. Genetics, 168, 435-446.

Kren, J., Klem K., Svobodova, I., Misa, P., Neudert L. (2014). Yield and grain quality of spring barley as affected by biomass formation at early growth stages. Plant Soil Environ., 60, 221-227.

Locmele, I., Legzdina, L., Gaile, Z., Kronberga, A. (2017). Estimation of yield and yield stability of spring barley genotype mixtures. In: Research for Rural Development. International Scientific Conference Proceedings, Vol. 2. Latvia University of Agriculture, pp. 19-25.

Lin, C. S., Binns, M. R. (1988). A superiority measure of cultivar performance for cultivar x location data. Can. J. Plant Sci., 68, 193-198.

Lui, G., Zhao Y., Mirdita, V., Reif, J. C. (2017). Efficient strategies to assess yield stability in winter wheat. Theor. Appl. Genet., 130 (8), 1587-1599.

Matusinsky, P., Svabodova, I., Misa, P. (2015) Spring barley stand structure as an indicator of lodging risk. Zemdirbyste-Agriculture, 102 (3), 273-280.

Mohammadi, R., Amir, A. (2008). Comparison of parametric and non-parametric methods for selection stable and adapted durum wheat genotypes in variable environments. Euphytica, 159, 419-432.

Muhleisen, J., Piepho, H. P., Maurer, H. P., Zhao, Y., Reif, J. C. (2014). Exploitation of yield stability in barley. Theor. Appl. Gen., 127 (9), 1949-1962.

Nissila, E. (1992). Yield stability parameters of barley under Finnish conditions. Acta Agricult. Scand., Section B Soil Plant Sci., 42, 152-157.

Nurminiemi, M., Bjornstad, A., Rognli, O. A. (1996). Yield stability and adaptation of Nordic barleys. Euphytica, 92 (1/2), 191-202.

Pandey, P., Irulappan, V., Bagavathiannan, M. V., Senthil-Kumar, M. (2017). Impact of combined abiotic and biotic stresses on plant growth and avenues for crop improvement by exploiting physio-morphological traits. Frontiers Plant Sci., 8, 537-552.

Peterson, C. J., Graybosch, P. S., Baenziger, P. S., Grombacher, A. W. (1992). Genotype and environment effects on quality characteristics of hard red winter wheat. Crop Sci., 32, 98-103.

Raisanen, J. (2017) Future climate changes in the Baltic Sea region and environmental impacts. The Oxford Research Encyclopedia, Climate Science, Oxford University Press, USA. 38 pp.

Sabaghinia, N., Mohammadi, M., Karimizadeh, R. (2013). Yield stability of performance in multi-environmental trials of barley (Hordeum vulgare L.) genotypes. Acta Universitatis Agriculturae Et Silviculturae Mendelianae Brunesis, 87 (3), 787-793.

Sterna, V., Zute, S., Jansone, I., Kantane, I. (2017). Chemical composition of covered and naked spring barley varieties and their potential for food production. Polish Journal of Food and Nutrition Sciences, 67 (2), 151-158.

Tamm, Y., Jansone, I., Zute, S., Jakobsone, I. (2015). Genetic and environmental variation of barley characteristics and the potential of local origin genotypes for food production. Proc. Latvian Acad. Sci., Section B, 69 (4), $163-169$.

Valkama, E., Salo, T., Esala, M., Turtola, E. (2013). Grain quality and N uptake of spring cereals as affected by nitrogen fertilization under Nordic conditions: A meta-analysis. Agricult. Food Sci., 22, 208-222. 


\section{LATVIJĀ SELEKCIONĒTO VASARAS MIEŽU ŠĶIRN̦U AGRONOMISKO UN GRAUDU KVALITĀTES PAZĪMJU STABILITĀTES NOVĒRTĒJUMS}

Pētījuma mērkis bija novērtēt agronomiskos un graudu kvalitātes rādītājus, un to stabilitāti 11 Latvijā selekcionētajām vasara miežu šķirnēm. Pētījums veikts 9 divkanšu miežu šķirnēm 'Abava', 'Ansis', 'Austris', 'Didzis', 'Gate', 'Idumeja', 'Jumara', 'Kristaps', 'Saule PR' un divām kailgraudu miežu šķirnēm 'Irbe' un 'Kornelija'. Lauka izmēǵinājumi iekārtoti Agroresursu un ekonomikas institūtā divās audzēšanas vietās (Priekuḷi un Stende) no 2014. līdz 2017. gadam. Graudu raža šḳirnēm 'Didzis', 'Jumara' un 'Ansis' būtiski pārsniedza vidējo ražu astonāās audzēšanas vietās $\left(5.70 \mathrm{t} \cdot \mathrm{ha}^{-1}, \mathrm{LSD}=0.476 \mathrm{t} \cdot \mathrm{ha}^{-1}\right)$. 'Didzis' uzrādīja salīdzinoši augstu dinamisko stabilitāti un plašu adaptivitāti visām audzēšanas vidēm ( $\mathrm{bi}=0.90 ; \mathrm{b}=1 ; \mathrm{s}_{\mathrm{d}}^{2}=0.07$ ). Graudu raža škirnei 'Jumara' parādīja pielāgošanās spēju mazāk labvēlīgiem audzēšanas apstākḷiem $\left(b_{i}=0.48 ; b 1 ; s^{2}{ }_{d}=0.09\right)$. Kopumā Latvijā selekcionētās škirnes pēc agronomiskajiem un graudu kvalitātes rādītājiem ir parādījušas atšḳirīgu reakciju dažādās vidēs. Starp plēkšṇainajiem miežiem identificētas šḳirnes ar paaugstinātu un stabilu 1000 graudu masu ('Austris', 'Idumeja'), tilpummasu ('Gate', 'Jumara', 'Austris'), augstu izturību pret Pyrenophora teres ('Didzis', 'Saule PR') un Blumeria graminis ('Saule PR', 'Didzis'). Kailgraudu miežu šḳirnēm 'Irbe' un 'Kornelija' bija pa gadiem paaugstināts kopproteīna un B-glikāna saturs graudos. 